\title{
Influence of recycled limestone filler additions on the mechanical behaviour of commercial premixed hydraulic lime based mortars
}

Jorge Segura ${ }^{\mathrm{a}, *}$, Diego Aponte ${ }^{\mathrm{a}}$, Luca Pelàa ${ }^{\mathrm{a}}$ Pere Roca ${ }^{\mathrm{a}}$

${ }^{a}$ Department of Civil and Environmental Engineering, Universitat Politècnica de Catalunya (UPCBarcelonaTech), 08034 Barcelona, Spain

* Corresponding author. Department of Civil and Environmental Engineering, Universitat Politècnica de Catalunya (UPC-BarcelonaTech), Jordi Girona 1-3, 08034 Barcelona, Spain. E-mail address: jorge.segura@upc.edu

Abstract: This paper presents an experimental programme aimed at investigating the use of limestone filler additions to modify the mechanical properties of commercial premixed hydraulic lime based mortars. The influence of adding recycled limestone filler was evaluated from the mechanical point of view, i.e. by comparing the experimental compressive and flexural strengths of five different mortar mixes with variable filler contents. The comparison of results shows that, up to a certain amount, the addition of filler provides an improvement of the mortar's mechanical properties. Beyond this optimum limit, strengths tend to decrease and eventually stabilize. Hence, mortars tested as part of this experimental campaign covered a range of strengths. Consequently, adding limestone filler can serve to adapt the applicability of hydraulic lime mortars to different practical applications, from the conservation of historical buildings to laboratory research on masonry.

Keywords: hydraulic lime mortar, limestone filler, compressive strength, flexural strength, historical mortars, commercial premix, X-ray diffraction. 


\section{Highlights:}

Limestone filler can be successfully incorporated into hydraulic lime mortars.

Mortars workability is maintained for amounts of filler replacement up to $50 \%$.

Mortar mechanical strengths reach a maximum for filler amounts within $12.5 \%-25 \%$.

Filler additions of $50 \%$ decrease and stabilize mechanical strengths beyond 28 days.

Possible applications are restoration works and laboratory research on masonry.

\section{Introduction}

Masonry buildings making use of hydraulic lime mortar as a constituent material represent a significant part of the architectural heritage [1], which includes structures built during the $19^{\text {th }}$ and the beginning of the $20^{\text {th }}$ centuries as well as older ones. In fact, after the findings of Smeaton in the $18^{\text {th }}$ century, hydraulic lime mortars were systematically used as building material [1-3].

The modern restoration philosophy recommends the use of repair products that are as compatible as possible with the substrate historical materials [4-6]. Therefore, the use of hydraulic lime mortars should be preferred in interventions on the aforementioned buildings. When compared to aerial lime mortars, hydraulic ones present a faster development of strengths and are able to harden under water, thanks to their double hardening mechanism that combines carbonation and hydration reactions [1]. In consequence, the use of hydraulic lime mortars is also encouraged to repair aerial lime-based masonry in cases where a quick hardening is needed or in structures exposed to severe environments $[3,4,7-11]$

Given the rise in the use of hydraulic lime mortar for restoration purposes [7], the research on this material has increased in the past two decades, with studies on the influence of the type of aggregates, the binder to water ratios and curing conditions on its properties $[1,6,8,11,12]$. The knowledge gathered through these and other experiences has allowed commercial companies to produce hydraulic lime based ready-mixed mortars that constitute an alternative to traditionally 
prepared ones [6]. Although these mortars have many advantages, two of them are particularly noteworthy. On one hand, their ease of use makes them available to less-skilled workers [13-15] since they only require adding water to the powder materials. On the other hand, their industrial preparation provides a certain standardization $[11,16]$ that increases the on-site homogeneity.

The research effort has continued in recent years with the double objective of producing enhanced mortars while incorporating different materials into the mix to reduce landfill waste $[17,18]$. Metakaolin [19], zeolite [20], diatomite [21] or fly ash [21] were added to hydraulic lime mortars to favour pozzolanic reactions and increase the mortar strengths. Barbero-Barrera et al. [22] studied the influence of graphite powder additions, which eventually improved the mortar's mechanical properties by filler and nucleation effects. The incorporation of organic additions, such as herbal [23] or cactus extracts [24], proved to have a beneficial impact on the overall properties thanks to the formation of side compounds. Some of the former mortars were specially designed to be used under severe environmental conditions of rain and freeze-and-thaw cycles, in high humidity and high temperature environments, or against acid erosion and salt crystallization.

Calcareous fines up to $100 \mu \mathrm{m}$, hereafter called limestone filler, may be also considered as a possible addition to hydraulic lime mortars. This material is an industrial by-product obtained in great quantities from limestone crushing and grinding [25-28]. Besides its application in asphalt mixes, limestone filler can be incorporated into concrete as well, not only when self-compaction is desired $[29,30]$, but also in common concretes as replacement of either cement or sand. This replacement results in at least three environmental advantages: a) reduction of waste to be landfilled [31], b) decrease of carbon dioxide $\left(\mathrm{CO}_{2}\right)$ emissions from the binder production [31,32], and c) reduction of natural or river sand needs in countries with a shortage in this material $[33,34]$.

The influence of limestone filler additions on concrete has been studied for decades [35-37]. Benachour et al. [25] and Wang et al. [38] offer a comprehensive review on the main mechanisms related to the incorporation of calcareous fines. A filler effect occurs because the fine particles fill the 
voids and increase the packing density of the material. The nucleation effect relates to the precipitation of hydration products by using the filler particles as nucleation sites. This fact accelerates the hydration reaction and improves the overall hydration of the paste. A limited chemical effect [38] takes place during the cement hydration, when the calcite $\left(\mathrm{CaCO}_{3}\right)$ from filler reacts with the aluminate $\left(\mathrm{C}_{3} \mathrm{~A}\right)$ and ferrite $\left(\mathrm{C}_{4} \mathrm{AF}\right)$ minerals of the paste to form carboaluminate. Finally, the dilution effect corresponds to the decrease within the mix of the cement content with respect to the other components. The positive or negative influence of the limestone filler on the global properties of the material would depend on the amount of filler and the combination of the former effects. A critical amount could be determined to optimise the concrete strength $[25,32,33,39,40]$.

A certain influence of limestone filler additions on non-hydraulic products has been identified as well. Fragata and Veiga [41] found higher strengths in aerial lime mortars prepared with two different types of aggregate when calcareous fines were added. Skoulidis et al. [42] found an optimal content of calcite that improved the mechanical behaviour of hydrated lime pastes used for the consolidation of stones. As the rate of carbonation of the calcium hydroxide (portlandite $\left.-\mathrm{Ca}(\mathrm{OH})_{2}\right)$ was also increased, they suggested that the calcareous particles could act as crystallization seeds for the carbonation process.

It may be assumed that effects similar to those described above for concrete and aerial lime mortars would take place in hydraulic lime mortars given their double hardening mechanism by carbonation and hydration. However, the duality of hydraulic limes also makes them more complex. Furthermore, their hydration products differ from those of cement [1]. More precisely, the major hydraulic phase in hydraulic limes is larnite (belite $-\mathrm{C}_{2} \mathrm{~S}$ ) instead of alite $\left(\mathrm{C}_{3} \mathrm{~S}\right.$ ), and $\mathrm{C}_{3} \mathrm{~A}$ and $\mathrm{C}_{4} \mathrm{AF}$ could be present but in very small amounts. In consequence, the influence of limestone filler on the hydraulic lime mortar properties may also be different and needs to be investigated. Two experiences have recently dealt with this topic. Forster et al. [43] analysed the influence of calcite additions in the form of oyster shells, limestone chippings and precipitated calcium carbonate. They found an increase 
on the mechanical strengths as result of these additions. Faria and Silva [11] studied the filler incorporation but combined with different aggregates and curing conditions. Besides the impact on the strengths, they found the calcareous filler to be advantageous, particularly with regard to water absorption and drying capability.

The present research is motivated by two related considerations. On one hand, there is an increase in the use of hydraulic lime mortars and commercial ready-to-use premixes for restoration purposes, together with a growing research on different material additions to improve the performance of these mortars. On the other hand, a lack of results has been detected about the influence of limestone filler additions on the mechanical behaviour of hydraulic lime mortars, while this addition, which is an abundant industrial by-product, has proven to be beneficial for both concrete and non-hydraulic lime mixes. With these considerations in mind, the present paper combines both research trends and explores the possibility of modifying the mechanical properties of hydraulic lime based mortars by incorporating limestone filler into their formulation. The influence of this addition has been evaluated from a mechanical point of view, i.e. in terms of changes in the compressive and flexural strengths of the mixture. The research involved five varied contents of filler, with the aim of covering a wide range of final applications.

\section{Materials and methods}

\subsection{Materials}

The experimental programme was carried out at the Laboratory of Technology of Structures and Building Materials of the Technical University of Catalonia (UPC - BarcelonaTech).

The mortars of this research were prepared by combining a hydraulic lime based commercial premix (HP) with limestone filler (LF) and water (W). The commercial product was a ready-to-use powder mix of binder and aggregates. A natural hydraulic lime NHL-3.5 as defined by EN 459-1 [44] acted as binder. The aggregates consisted of two types of washed river silica sand $(0.1 \div 0.5 \mathrm{~mm}$ and 
$0.1 \div 1 \mathrm{~mm})$ and pure white marble powder $(0 \div 2.5 \mathrm{~mm})$. The unit weight of this blend was determined to be $1740 \mathrm{~kg} / \mathrm{m}^{3}$.

The manufacturer supplied the former premix in $25 \mathrm{~kg}$ bags. The content of one bag was studied. First, it was conveniently reduced by means of a quartering device to obtain a representative sample. This sample was divided into two fractions, one being the material passing through the 0.063 $\mathrm{mm}$ sieve and the other the material retained in the $0.063 \mathrm{~mm}$ sieve. Both fractions were analysed by X-ray diffraction with a PANalytical X'Pert PRO MPD Alpha 1 diffractometer using Cu Ka radiation $(\lambda=1.5406 \AA(45 \mathrm{kV}-40 \mathrm{~mA}))$. Fig. 1 presents those results. The diffractogram of the finer fraction (Fig. 1a) indicates the presence of the binding compounds, namely the hydraulic phases larnite and alite with a predominance of the former, as well as portlandite. This composition is in agreement with that of any hydraulic lime based binder [1,6]. The diffractogram of the coarser fraction (Fig. 1b) shows calcite as the main mineralogical phase, together with a reduced presence of quartz. This is consistent with the base materials defined in the former paragraph, silica sand and marble powder. Given the nature of the aggregates and both diffractograms, and according to a similar procedure adopted in [6] for the study of commercial NHL mortars, it could be assumed that the material passing the $0.063 \mathrm{~mm}$ sieve corresponded to the binder while the material retained in the $0.063 \mathrm{~mm}$ corresponded to the aggregates. This assumption was applied to compute an approximate binder to aggregates weight ratio of the hydraulic commercial premix that was 1:3.22. Lastly, the particle size distribution of the aggregates fraction was determined by sieving according to the standard EN 933-1 [45]. Fig. 2 displays the resulting chart, which corresponded to a well-graded fine aggregate. 

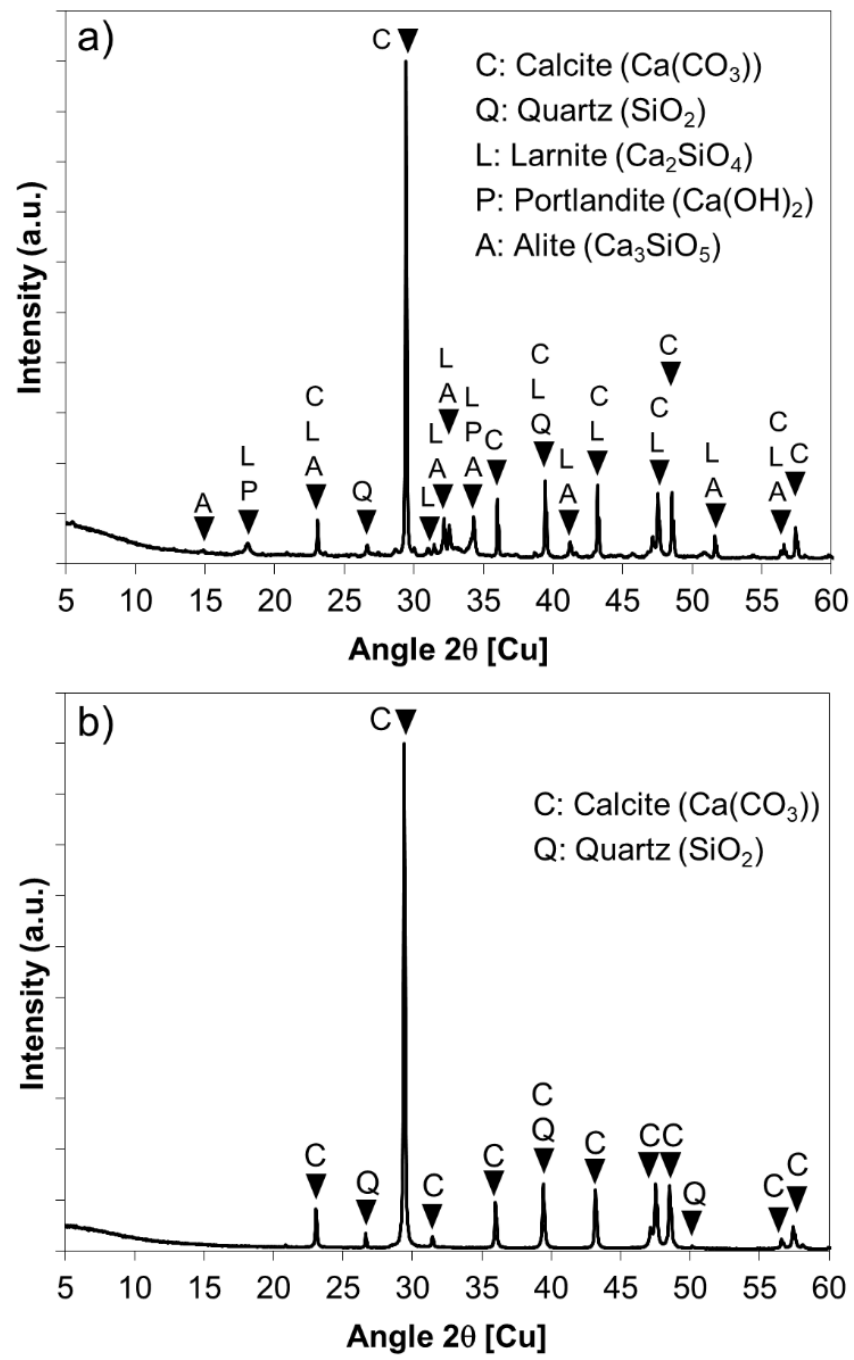

Fig. 1 XRD diffractograms in the $5-60^{\circ} 2 \theta$ angular region of the anhydrous premix. a) Fraction passing the 0.063 $\mathrm{mm}$ sieve, b) fraction retained in the $0.063 \mathrm{~mm}$. 


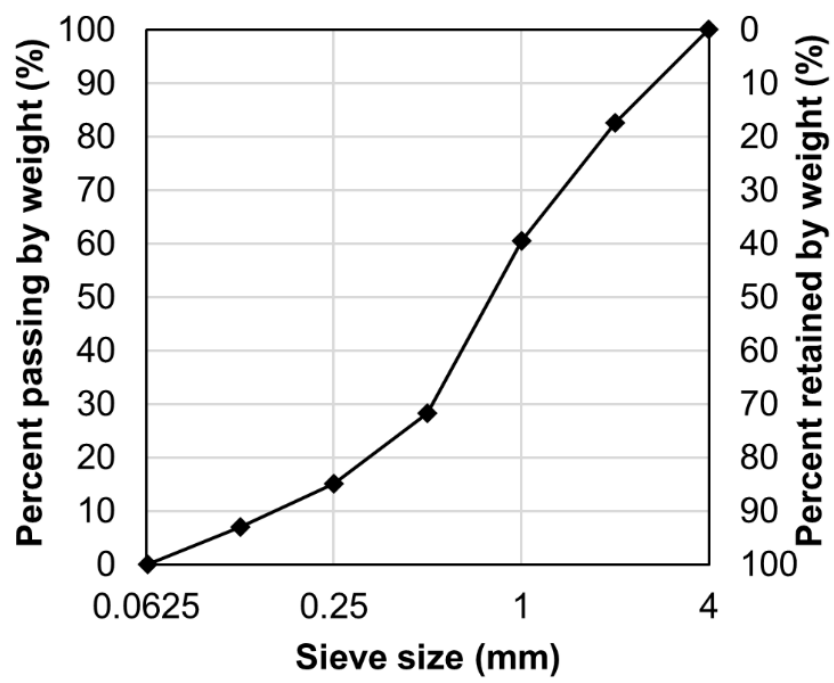

Fig. 2 Determination of the particle size distribution chart of the premix aggregates.

The limestone filler incorporated into the mortars was supplied by a company that obtained it as a by-product of limestone grinding. A representative sample was studied. First, the unit weight of the filler was determined to be $1120 \mathrm{~kg} / \mathrm{m}^{3}$ and its fineness was confirmed since $100 \%$ of the material passed through the $0.063 \mathrm{~mm}$ sieve. The particle size was analysed in more detail by means of a polarized light microscope JenaPol. Fig. 3 includes microscope images with a magnification of 100X of limestone filler particles that had been previously dispersed in oil. These images show that all particles were smaller than $50 \mu \mathrm{m}$ and presented variability of shapes. Finally, Fig. 4 displays the results of an X-ray diffraction of the filler that indicate, as should be expected, the total predominance of calcite as main mineralogical phase. The presence of kaolinite, quartz and muscovite was incidental and could be originated in clays present during the initial extraction of the material. Therefore, the incorporation of the recovered limestone powder into the mortars did not add any harmful substance. 

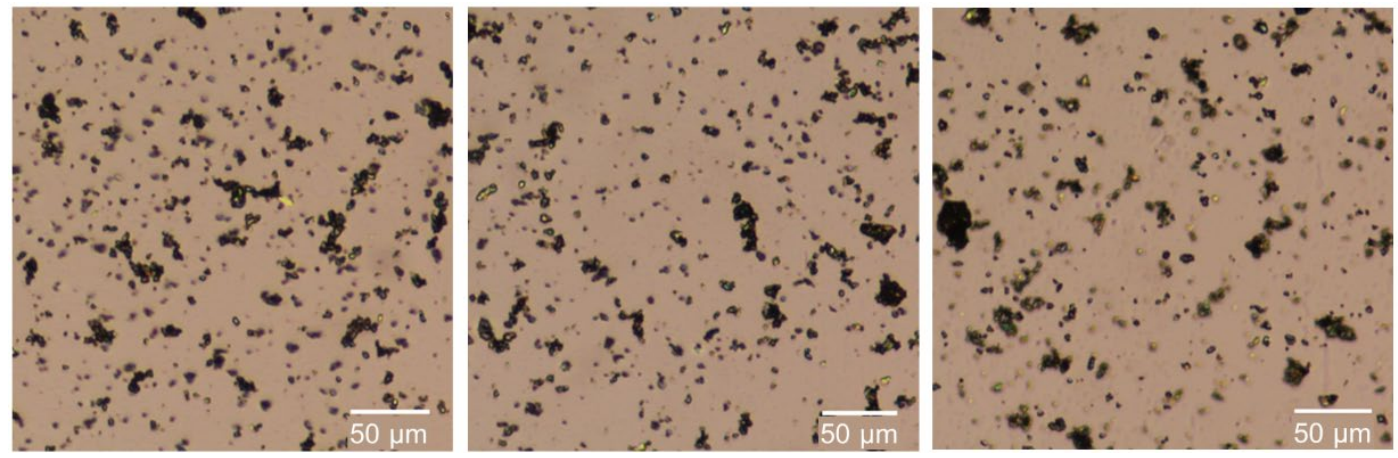

Fig. 3 Polarized light microscope images of limestone filler particles dispersed in oil. Magnification 100X. Scale 50 $\mu \mathrm{m}$.

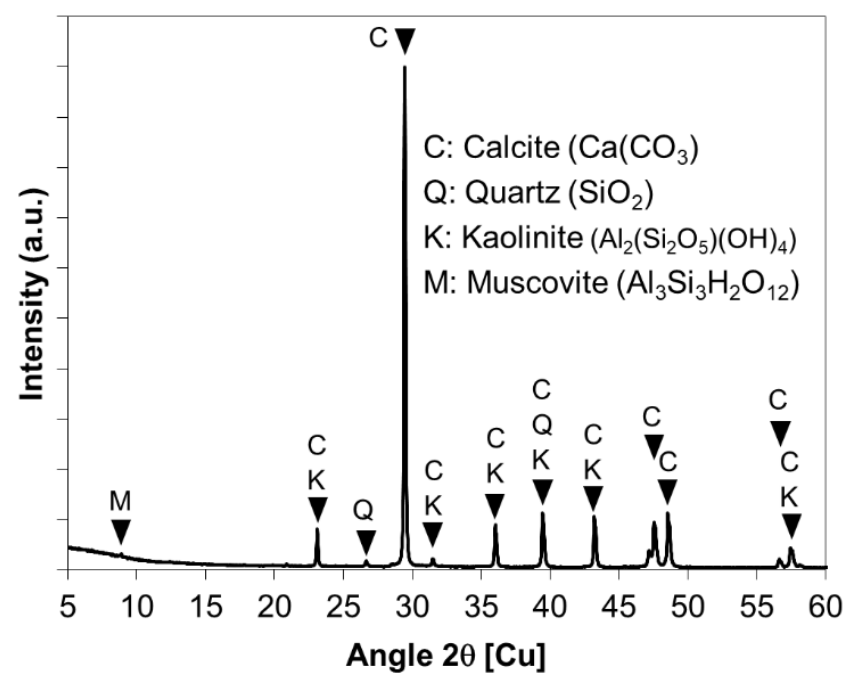

Fig. $4 \mathrm{XRD}$ diffractogram in the $5-60^{\circ} 2 \theta$ angular region of limestone filler.

\subsection{Mortars design}

The reference mortar, here identified as mix M0, consisted only of hydraulic commercial premix and water. To investigate the influence of the limestone filler additions, four mortars with increasing filler content were defined. Table 1 indicates the content of the two different constituents for the reference mix M0 and the modified mixes MA, MB, MC and MD. This content is indicated as a percentage of the total powder volume. Fig. 5a shows graphically the mortars definition, which ranged from MA, with a substitution by filler of only $12.5 \%$ of the total powder volume, to MD, where half the volume was substituted by filler. The weight proportions of the powder materials displayed in 
Fig. $5 \mathrm{~b}$ were calculated with the bulk densities and the binder to aggregate ratio found in the previous section 2.1. The chart shows how the proportion of binder decreased with the progressive addition of filler.

Table 1 Mortars definition in terms of total powder volume replaced by limestone filler.

\begin{tabular}{ccc}
\hline \multirow{2}{*}{ Mortar } & \multicolumn{2}{c}{ Powder volume (\%) } \\
\cline { 2 - 3 } & Hydraulic premix (HP) & Limestone filler (LF) \\
\hline M0 & 100 & 0 \\
MA & 87.5 & 12.5 \\
MB & 75 & 25 \\
MC & 62.5 & 37.5 \\
MD & 50 & 50 \\
\hline
\end{tabular}



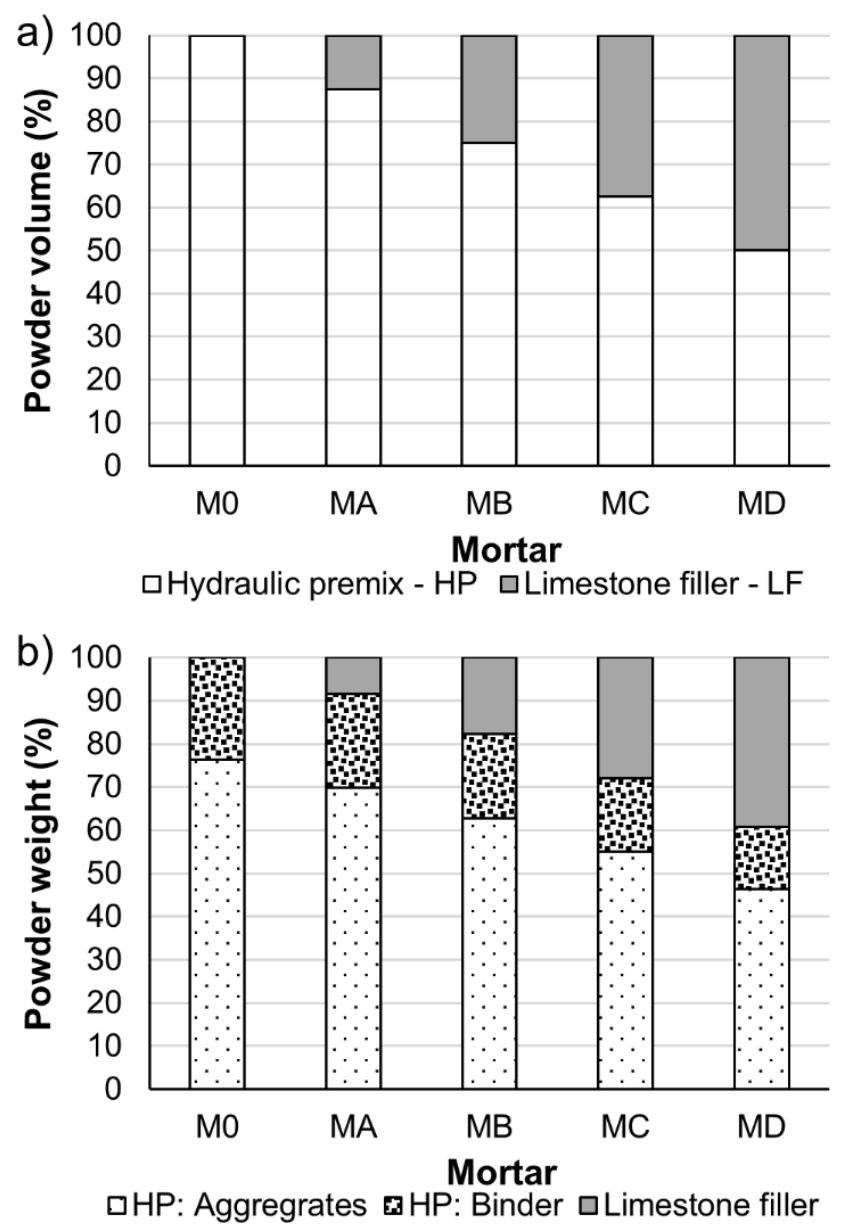

Fig. 5 Graphical representation of mortars proportioning, a) by percentage of total powder volume and b) by percentage of total powder weight.

The mortars design was completed by determining the water content of each mix. A batch of reference mix M0 was prepared according to the prescriptions of the manufacturer, i.e. 4.51 of water every $25 \mathrm{~kg}$ of hydraulic commercial premix. The consistence of the fresh mortar was evaluated by means of the flow table test described in the standard EN 1015-3 [46]. A metallic mould was filled with two compacted layers of fresh mortar. After removing the mould and jolting the table 15 times, the result of the test was obtained as the mean diameter of the spread mortar measured in two directions at right angles. The flow value of $168.5 \mathrm{~mm}$ measured for mix M0 was considered acceptable in terms of workability [12] and was selected as a target consistence for the rest of the mortars. The water content of the other mixes was determined by a trial-error process until obtaining the required 
consistence. Table 2 indicates the water contents and flow values for all the mixes, and the complete proportioning by volume and by weight as well.

Table 2 Mortars proportioning by volume and by weight, and flow measured according to EN 1015-3 [46].

\begin{tabular}{|c|c|c|c|c|c|c|c|c|}
\hline \multirow[b]{2}{*}{ Mortar } & \multicolumn{3}{|c|}{ Proportions by volume } & \multicolumn{4}{|c|}{ Proportions by weight } & \multirow[b]{2}{*}{$\begin{array}{l}\text { Flow } \\
(\mathrm{mm})\end{array}$} \\
\hline & $\begin{array}{c}\text { Hydraulic } \\
\text { premix } \\
\text { (HP) } \\
\end{array}$ & $\begin{array}{l}\text { Limestone } \\
\text { filler (LF) }\end{array}$ & $\begin{array}{l}\text { Water } \\
\text { (W) }\end{array}$ & $\begin{array}{c}\text { HP: } \\
\text { Aggregates }\end{array}$ & $\begin{array}{l}\text { HP: } \\
\text { Binder }\end{array}$ & $\begin{array}{l}\text { Limestone } \\
\text { filler }\end{array}$ & Water & \\
\hline M0 & 1 & 0 & 0.312 & 0.763 & 0.237 & 0 & 0.180 & 168.5 \\
\hline MA & 1 & 0.143 & 0.357 & 0.763 & 0.237 & 0.092 & 0.206 & 169.3 \\
\hline MB & 1 & 0.333 & 0.416 & 0.763 & 0.237 & 0.215 & 0.240 & 167.8 \\
\hline $\mathrm{MC}$ & 1 & 0.600 & 0.499 & 0.763 & 0.237 & 0.387 & 0.288 & 165.5 \\
\hline MD & 1 & 1 & 0.650 & 0.763 & 0.237 & 0.645 & 0.375 & 167.1 \\
\hline
\end{tabular}

\subsection{Specimens preparation and testing}

The influence of the limestone filler additions on the mechanical behaviour of hydraulic mortars was investigated by means of the evaluation and comparison of two mechanical properties, namely the flexural and compressive strengths of the material. The European standard EN 1015-11 [47] covers the testing of these two properties on hardened mortars. The experimental work presented herein followed the specifications of the standard.

A set of nine test specimens was built for each mortar. The specimens were $160 \times 40 \times 40 \mathrm{~mm}^{3}$ (length $\times$ width $\times$ depth) prisms casted in metallic moulds. The mix of the three constituents, i.e. commercial hydraulic lime based premix, filler and water, was carried out for each mortar type with a mixer following the times prescribed by EN 196-1 [48]. After mixing, the fresh mortars were poured into the moulds in two approximately equal layers. Each layer was compacted by 25 strokes of a standard tamper. A palette knife was used to skim off the excess mortar to ensure surfaces plane and levelled with the top of the moulds. Each mould was then placed in an individual sealed polyethylene bag. Although the standard EN 1015-11 [47] recommends to remove the prisms from the mould after $48 \mathrm{~h}$, the prisms were demoulded after $72 \mathrm{~h}$ because it was found preferable due to the slower hardening 
of the less strong mixes. After the demoulding, the prisms were kept again inside the bags for four additional days. Once extracted, they were stored in laboratory conditions until the age of testing (15 $\pm 5^{\circ} \mathrm{C}$ and $\left.\mathrm{RH} 65 \pm 10 \%\right)$.

The mortar prisms were tested, in sets of three specimens, at 14, 28 and 56 days. Testing at different ages was important to investigate the evolution of the properties with time. An age of 56 days was considered a sufficient time to carry out the comparison among mixes given the faster hardening of hydraulic lime compared to aerial lime mortars, which are usually tested after 90 days $[7,41,49]$. The flexural strength of the prisms $\left(f_{\text {flex }}\right)$ was determined by means of three-point bending tests (Fig. 6a) and evaluated according to the following expression (Eq. 1):

$$
f_{\text {flex }}=1.5 * \frac{F l}{b d^{2}}
$$

where $F$ is the maximum load applied to the specimen, $l$ is the distance between the axis of the support rollers, which is equal to $100 \mathrm{~mm}$, and $b$ and $d$ are the width and depth of the specimen respectively.

The two halves of the prisms broken during the bending tests were kept and tested under compression. A specific laboratory jig (Fig. 6b) ensured that the loaded area $(A)$ was a $40 \times 40 \mathrm{~mm}^{2}$ square. The compressive strength of the mortar $\left(f_{\text {comp }}\right)$ was evaluated with the following expression (Eq. 2):

$$
f_{\text {comp }}=\frac{F}{A}
$$

Both types of test were carried out with a $10 \mathrm{kN}$ capacity compression machine. No additional measuring devices were placed to capture the displacements during the tests. In all cases, the loading rates were selected so that failure occurred after 30 seconds. 

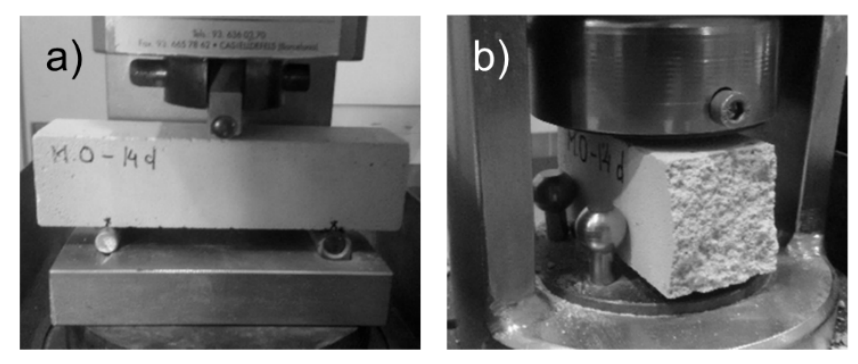

Fig. 6 Mortar testing setup. a) Three-point bending and b) compression tests.

\section{Results and discussion}

Table 3 and Table 4 present the average 14, 28 and 56-day flexural and compressive strengths of all mortar types. The associated coefficients of variation are included in brackets. Fig. 7 and Fig. 8 plot the development of strengths over curing time. The results show the influence of limestone filler on the mechanical behaviour of hydraulic lime mortar and how it was dependent, as could be expected, on the amount of filler. However, the results also show that the trend of this influence varied with the curing time and slightly differed depending on the mechanical property investigated.

At 14 days, mortar MD (50\% LF) was the weakest in both flexion and compression. M0 ( $0 \%$ LF) was the strongest mortar in compression but MA (12.5\% LF) and MB (25\% LF) were stronger in flexion. Yet, differences between mixes were minor at this early age. At 28 days, the influence of filler additions was reflected in a reduction of the flexural and compressive strengths, which decreased as the amount of filler increased. At 56 days, conversely, M0 (0\% LF) was not the strongest mortar. After two months of curing, the flexural strength of mortar MA $(12.5 \% \mathrm{LF})$ was $8 \%$ higher than the reference one (M0) and $128 \%$ higher than the weakest mortar one (MD), while mortar MB (25\% LF) was $35 \%$ stronger than the reference mortar M0 and $177 \%$ stronger than the weakest mortar MD in compression.

Among the 30 average results presented in Table 3 and Table 4, only three exhibited a high variability with coefficients of variation "CV" around 15\%. The latter is often found for lime-based mortars [50]. Furthermore, one third of the average results had a coefficient of variation lower than 
5\%. The strength decrease captured for certain mixes between 28 and 56-day tests has been also registered in previous research works available in the relevant literature $[1,8,12,19,41,43,49,51]$. Some authors pointed out that this behaviour could be attributed to the development of microcracking [8] or changes within the pore structure [43].

Table 3. Flexural strength of mortars $\left(f_{f l e x}\right)$. Average values at 14, 28 and 56 days for each mortar. Coefficients of variation shown in brackets.

\begin{tabular}{lllllll}
\hline \multirow{2}{*}{ Mortar } & \multicolumn{9}{c}{$f_{\text {flex }}(\mathrm{MPa})$} \\
\cline { 2 - 7 } & \multicolumn{2}{c}{14 days } & \multicolumn{2}{c}{28 days } & \multicolumn{2}{c}{56 days } \\
\hline M0 - 0\% LF & 0.94 & $(10.4 \%)$ & 1.93 & $(7.6 \%)$ & 1.64 & $(5.1 \%)$ \\
MA - 12.5\% LF & 1.19 & $(1.7 \%)$ & 1.83 & $(3.1 \%)$ & 1.76 & $(3.8 \%)$ \\
MB - 25\% LF & 1.10 & $(3.9 \%)$ & 1.64 & $(9.1 \%)$ & 1.55 & $(11.0 \%)$ \\
MC - 37.5\% LF & 0.81 & $(15.9 \%)$ & 1.03 & $(4.5 \%)$ & 1.22 & $(8.5 \%)$ \\
MD - 50\% LF & 0.65 & $(15.1 \%)$ & 0.68 & $(9.9 \%)$ & 0.77 & $(2.2 \%)$ \\
\hline
\end{tabular}

Table 4. Compressive strength of mortars $\left(f_{\text {comp }}\right)$. Average values at 14,28 and 56 days for each mortar. Coefficients of variation shown in brackets.

\begin{tabular}{lllllll}
\hline \multirow{2}{*}{ Mortar } & \multicolumn{9}{c}{$f_{\text {comp }}(\mathrm{MPa})$} \\
\cline { 2 - 7 } & \multicolumn{1}{c}{14 days } & \multicolumn{2}{c}{28 days } & \multicolumn{2}{c}{56 days } \\
\hline M0 - 0\% LF & 2.89 & $(12.8 \%)$ & 4.47 & $(7.5 \%)$ & 3.78 & $(9.1 \%)$ \\
MA - 12.5\% LF & 2.58 & $(3.4 \%)$ & 4.35 & $(5.4 \%)$ & 4.82 & $(5.1 \%)$ \\
MB - 25\% LF & 2.39 & $(3.5 \%)$ & 4.00 & $(4.1 \%)$ & 5.09 & $(15.2 \%)$ \\
MC - 37.5\% LF & 2.11 & $(8.9 \%)$ & 3.15 & $(8.3 \%)$ & 3.60 & $(8.3 \%)$ \\
MD - 50\% LF & 1.64 & $(5.3 \%)$ & 1.91 & $(6.4 \%)$ & 1.83 & $(4.2 \%)$ \\
\hline
\end{tabular}




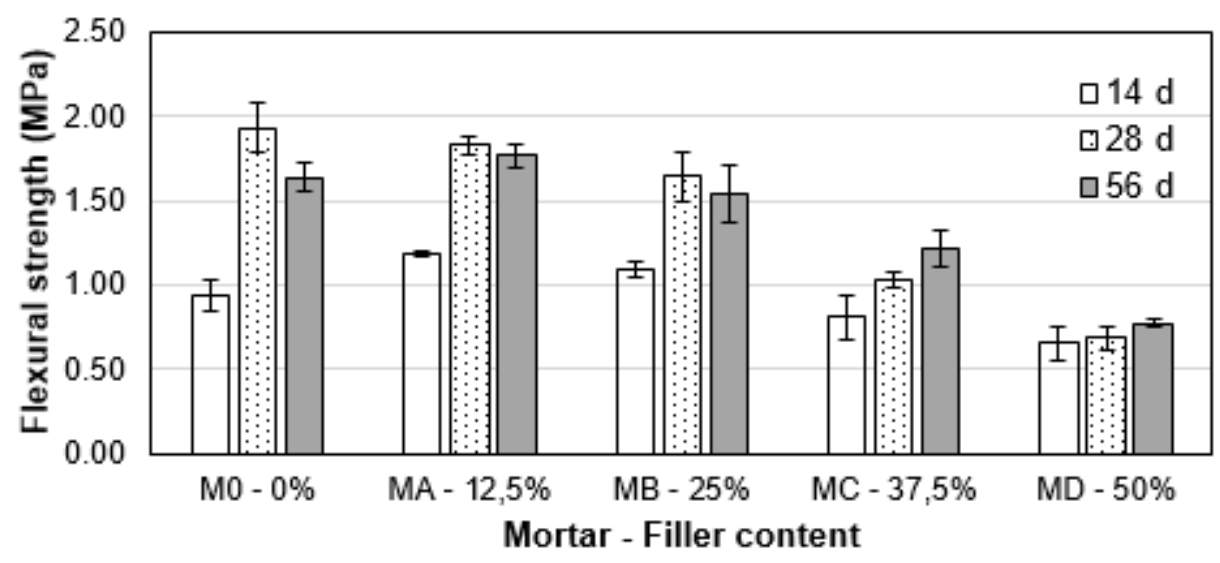

Fig. 7 Flexural strength of mortars $\left(f_{\text {flex }}\right)$. Bars represent the average values at 14, 28 and 56 days for each mortar. Whiskers indicate the average values \pm 1 standard deviation.

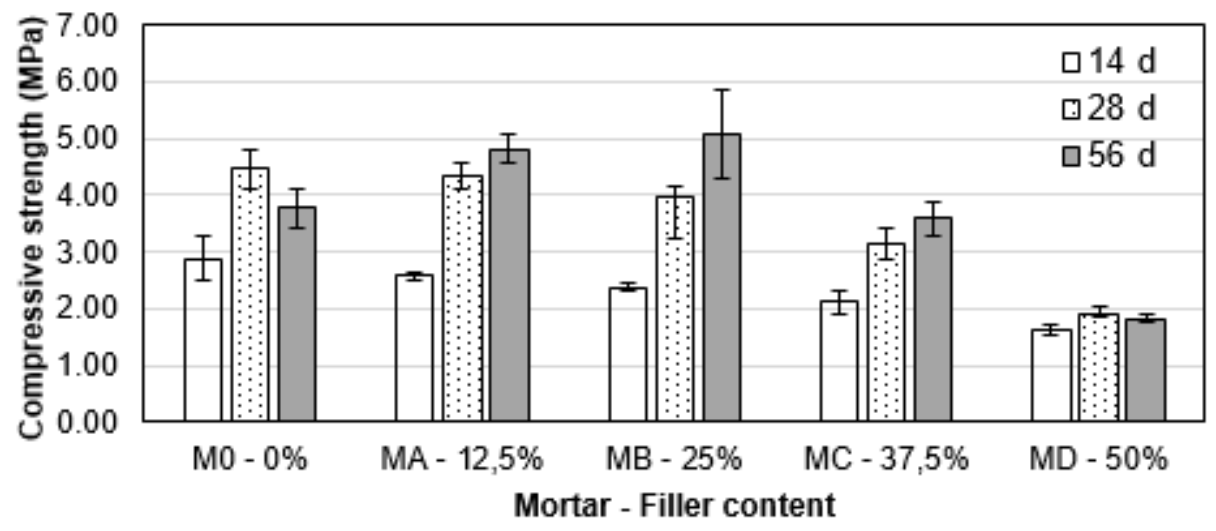

Fig. 8 Compressive strength of mortars $\left(f_{\text {comp }}\right)$. Bars represent the average values at 14, 28 and 56 days for each mortar. Whiskers indicate the average values \pm 1 standard deviation.

As discussed in Section 1, the incorporation of calcareous fines may have different effects on the strength development of mortars. Namely, the filler effect that increases the packing density, the nucleation effect that favours the hydration and carbonation reactions, and the dilution effect acting when the binder is not able to coat all the particles. As the two former tend to oppose the latter, the global observed influence would depend, among others, on the amount of filler added. The combination of the three main effects can explain the experimental results presented in this paper. At 14 days, the dilution effect motivated the progressive reduction of compressive strength registered for increasing amounts of filler. Conversely, the greater packing density provided by the filler effect was 
sufficiently important in flexion in the cases of mortars MA $(12.5 \% \mathrm{LF})$ and $\mathrm{MB}(25 \% \mathrm{LF})$ to counteract the dilution and both mortars reached higher flexural strengths compared to the reference M0 ( $0 \%$ LF). At 28 days, the dilution effect seemed to prevail over the rest as mortar M0 consistently exhibited higher strengths in both flexion and compression. However, at 56 days, a positive influence in both compressive and flexural strengths was observed that might be attributed to the nucleation effect. This mechanism is related to the hardening reactions of mortar, the hydration of $\mathrm{C}_{2} \mathrm{~S}-$ which is slower than the hydration of $\mathrm{C}_{3} \mathrm{~S}$ in cement mortars- and the carbonation of $\mathrm{Ca}(\mathrm{OH})_{2}$. Therefore, it required a certain time to be detected. With regard to the mortar MD incorporating $50 \%$ of limestone filler, the dilution effect predominated in such extent that the strength evolution was stopped even at 14 days. For this mix, the mechanical strengths showed almost constant values during the three ages of testing.

The objective of this work was to study the incorporation of limestone filler into commercial hydraulic lime based mixes to design modified mortars. From that point of view, the research provided a variety of results. At 28 days, mortar MA with a replacement with filler of $12.5 \%$ reached strengths similar to those of the reference mortar M0. At 56 days, an optimum could be found between MA $(12.5 \% \mathrm{LF})$ and $\mathrm{MB}(25 \% \mathrm{LF})$ to produce the mortar with the highest flexural and compressive strengths. The strength of $5 \mathrm{MPa}$ exhibited by these two mixes in compression compares well with the results of Xu et al. [21] who added diatomite, Grilo et al. [19] who investigated metakaolin additions or Lanas et al. [1] who started from a stronger hydraulic lime. Those mortars might be suitable for restoration of structures in severe environments [19]. Additionally, mortar MD (50\% LF) presented certain features that might be suitable for research purposes as discussed in Section 4.

Fig. 9 plots the compressive $\left(f_{\text {comp }}\right)$ to flexural $\left(f_{\text {flex }}\right)$ strength ratios $\left(f_{\text {comp }} / f_{\text {flex }}\right)$ computed for all mortar types and grouped for the different ages. The graphs did not allow identifying any regular trend but showed that all the values ranged between 2.1 and 3.3. Fig. 10 was elaborated thanks to the great number of available test data, as it compares the total 180 results in compression to the 90 results in 
flexion regardless of the age and the filler content. Even if the coefficient of determination $R^{2}$ was $79 \%$, the ratio of 2.57 may be considered as representative of the types of mortar studied herein.

Allen [52] indicated that the compressive to flexural strengths ratio relates inversely to the brittleness and directly to the plasticity of the material. Kalagri et al. [8] found this ratio to be proportional to the dynamic modulus of elasticity. The 2.57 estimated ratio is similar to the ratios found in other researches with hydraulic and aerial lime mortars $[5,8,11,49,53]$ on the same type of tested specimen.

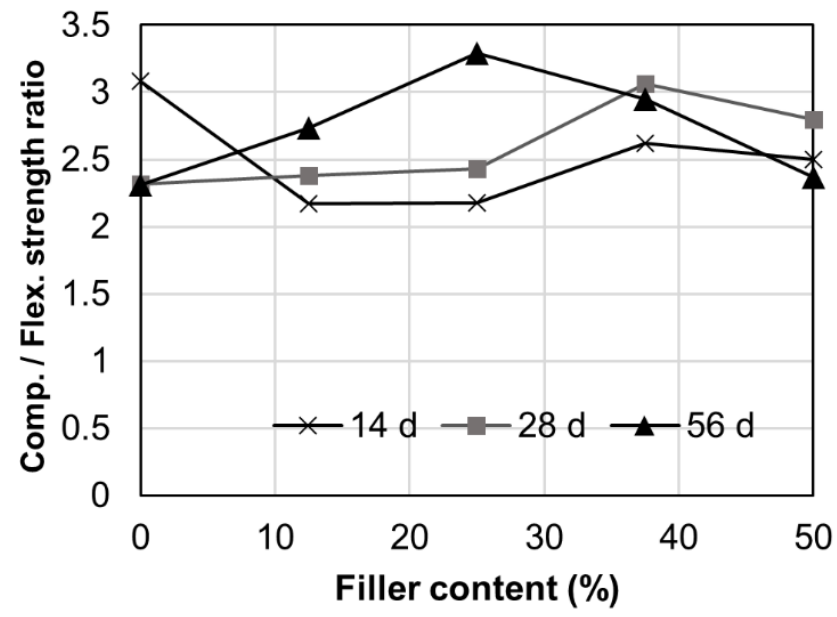

Fig. 9 Ratio between compressive $\left(f_{\text {comp }}\right)$ and flexural strength $\left(f_{\text {flex }}\right)$ of mortars for each filler content at 14, 28 and 56 days. 


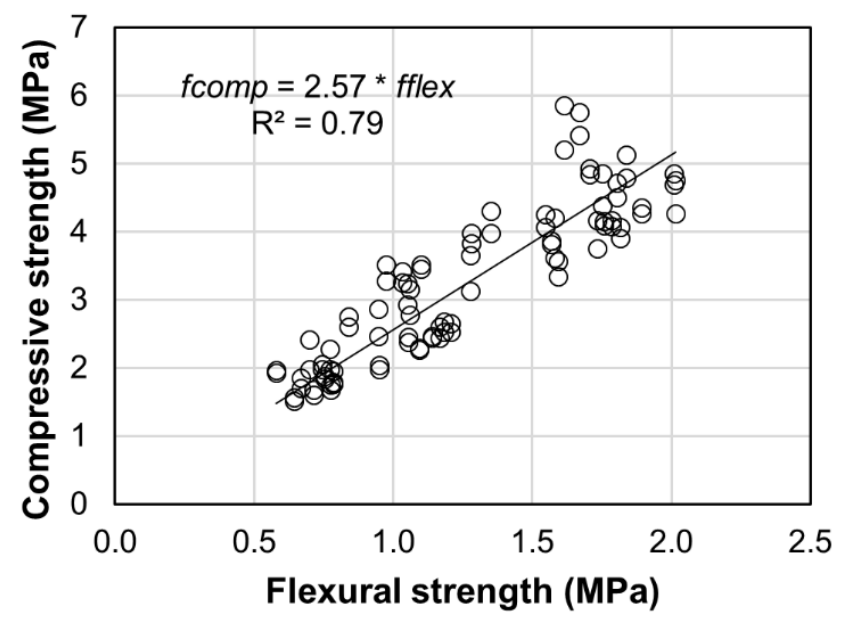

Fig. 10 Correlation between compressive $\left(f_{\text {comp }}\right)$ and flexural strength $\left(f_{f l e x}\right)$ by combining the available data from all types of mortar and ages.

\section{Example of application of mortar with limestone filler replacement of $50 \%$}

The previous section has shown that replacing the $50 \%$ of powder volume by limestone filler (mortar MD) leads to a strength reduction of the commercial premixed hydraulic lime based mortar down to $2 \mathrm{MPa}$. This strength value can be considered representative of a historical mortar $[7,11,54,55]$ and makes mortar MD suitable to satisfy a need encountered in the research field.

Research on historical masonry usually involves building structures or structural elements in laboratory that try to replicate the properties of the real ones [56-58]. This implies the use of low strength mortars, but preferably with a certain hydraulicity to guarantee a fast hardening and to reduce the curing time needed before testing. Some researchers may choose the option of commercially available hydraulic lime premixes because of the homogeneity and easy use offered by an industrial product as exposed in section 1. In some cases, however, these materials develop a too high compressive strength and may not be adequate to replicate a historical mortar. In fact, as investigated by Gulotta et al. [6], some of these mortars may reach strengths much higher than the strengthresistance classes of the initial binders. 
In order to address this issue, some authors have incorporated additions into the commercial premixes to combine the advantages of the latter with a convenient strength level. Magenes et al. [59] modified a hydraulic lime based commercial mortar by replacing $22 \%$ of the volume with sand. More recently, Guerrini et al. [60] added EPS beads up to $28 \%$ of the volume. Both cases achieved an appropriate strength reduction.

During recent years, the mortar mix MD has been used in the Laboratory of Technology of Structures and Building Materials of the Technical University of Catalonia (UPC) in different experimental campaigns that aimed to study historical-like masonry elements $[61,62]$. Fig. 11 shows the results of bending and compression characterization tests on prisms of mortar MD corresponding to the last campaigns carried out at UPC. A total amount of 60 and 120 results are displayed for flexural and compressive strengths respectively. The charts cover different ages from 7 to 112 days. As discussed in the previous section, the incorporation of such amount of filler seemed to stop the strength development of the mortar at an early age. The average flexural and compressive strengths after 28 days were 0.71 and $1.93 \mathrm{MPa}$ respectively and the individual test results exhibited a close oscillation around those values. The related coefficients of variation, computed with all the data after 28 days, were $16.8 \%$ and $12.9 \%$. Taking into account the variability within the material, the differences in curing conditions and the inherent scattering of the experimental tests, those coefficients of variation allow considering the strengths as constant over time. The overall ratio $f_{\text {comp }} / f_{\text {flex }}$ was 2.72 , which is consistent with the values displayed in Fig. 9. 

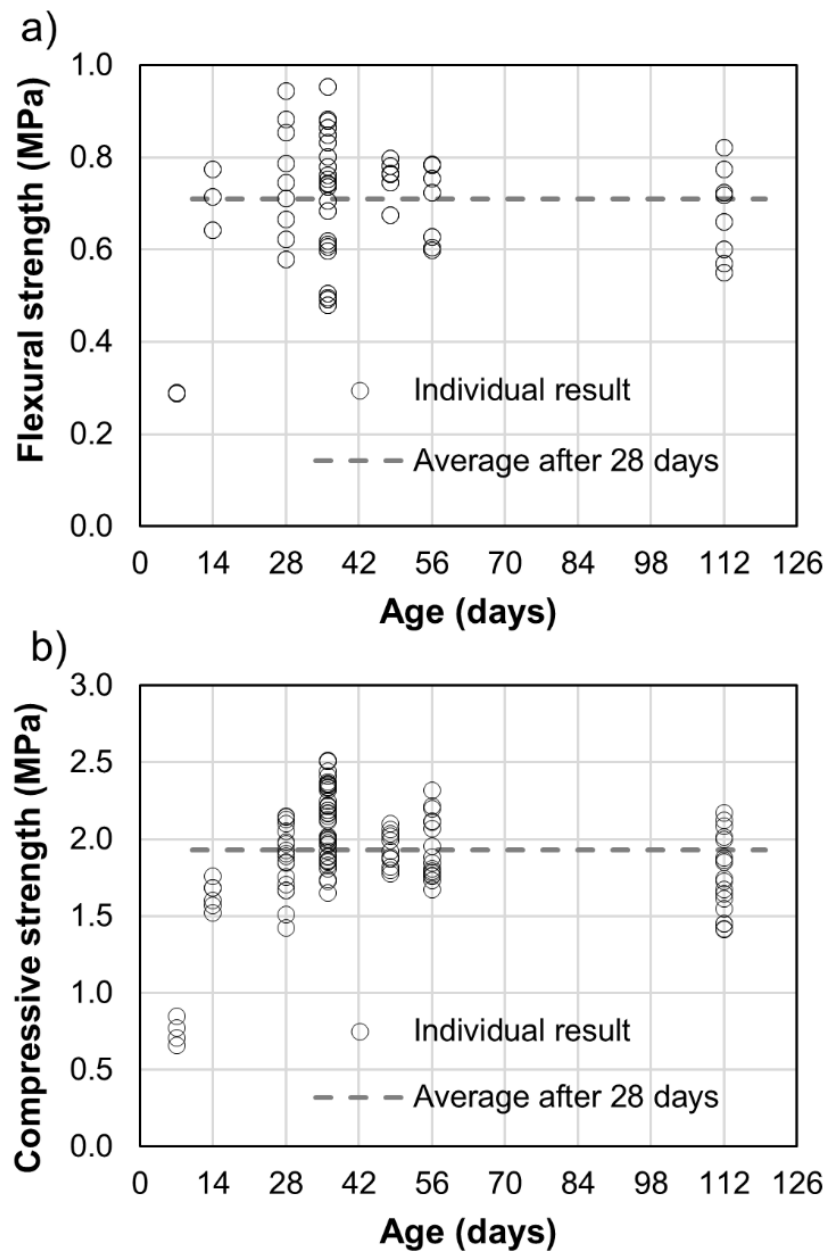

Fig. 11 Strength evolution of mortar MD with age. The dashed lines indicate the average value of the strengths considering all the individual results after 28 days. a) Flexural strength, b) compressive strength.

The characterization of this mortar MD was completed with two additional tests. On one hand, Fig. 12 shows three images of mortar joint sections obtained with a stereo microscope Leica using incident light. These pictures, with a magnification of 10X, illustrate the macrostructure of the hardened mortar at 56 days and reveal a porous material, with pores occasionally bigger than $2 \mathrm{~mm}$. The incorporation of filler did not saturate the pore structure and in consequence the mortar could be able to breath and carbonate easily. On the other hand, Fig. 13a displays the X-ray diffractogram of a sample of hardened mortar MD at 56 days after crushing and mechanical sieving. The results show that, at that time, there was a very limited amount of binding compounds (larnite, portlandite) left. Fig. $13 \mathrm{~b}$ clarifies this aspect as it compares the diffractogram of the hardened mortar to that of the 
anhydrous original premix. The absence or reduction of the peaks related to the binding phases is especially noted in the $18,30-35,40-452 \theta$ angular regions. This fact involves a limited evolution of strengths after 56 days, consistently with the mechanical tests previously presented in Fig. 11 that yielded constant strengths between 56 and 112 days. It is also remarkable that the final products in the hardened mortar, namely calcite and traces of quartz, are the same of those of any hydraulic lime based mortar. This result together with the favourable pore structure imply that mortar MD, in case of being used in restoration works, would not present any compatibility issues with the traditional old substrate materials. Given that mortar MD was the mix with the highest amount of limestone filler, the former conclusions related to final resulting products, pore structure and compatibility would be also applicable to the rest of mixes studied in Section 3.
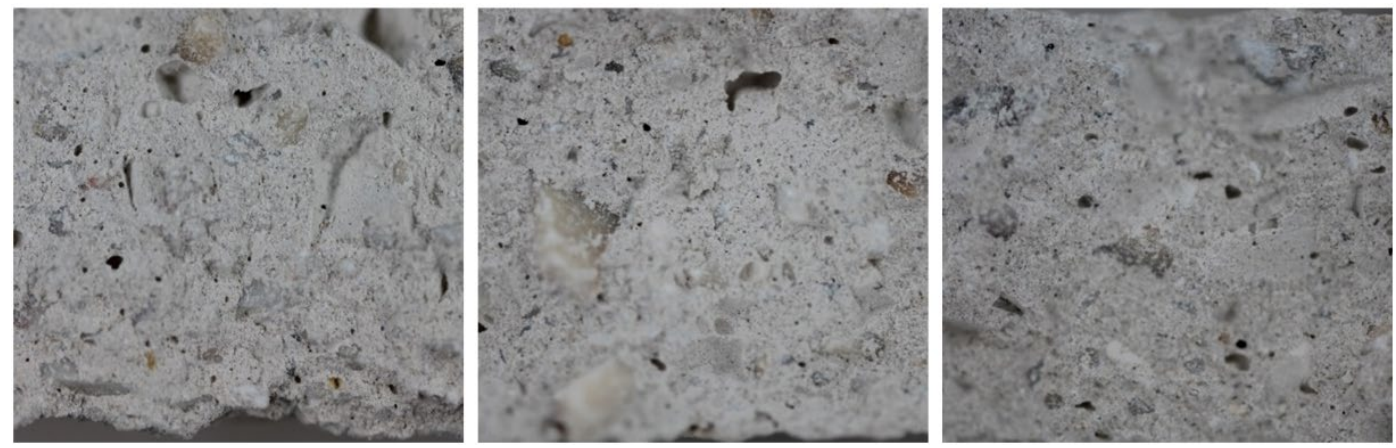

Fig. 12 Stereo microscope images of hardened mortar MD joint sections after 56 days. Magnification 10X. 

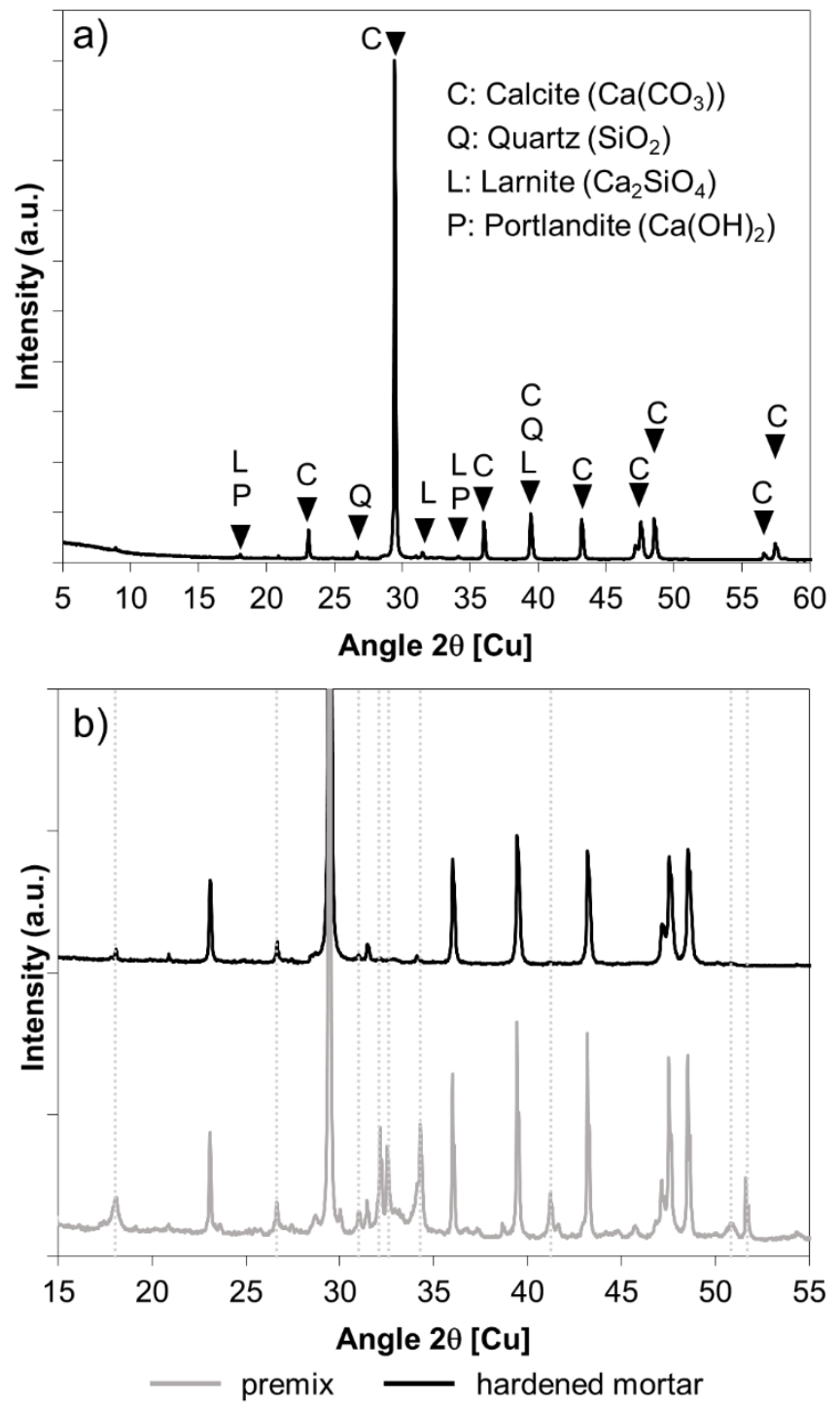

Fig. 13 a) XRD diffractogram in the $5-60^{\circ} 2 \theta$ angular region of hardened mortar MD at 56 days after crushing and mechanical sieving; b) comparison of XRD diffractograms in the $15-55^{\circ} 2 \theta$ angular region of anhydrous premix (see Fig. 1a) and hardened mortar MD at 56 days.

Additionally, mortar MD was used to build small masonry specimens with handmade solid clay bricks by the authors [61]. Bricks had average dimensions of $311 \times 149 \times 45 \mathrm{~mm}^{3}$ and a normalized compressive strength of $18 \mathrm{MPa}$. Running bond walls and stack bond prisms were tested in compression providing average compressive strengths of 6.51 MPa and 6.75 MPa respectively. These values may be representative of historical masonry elements as they compare well with laboratory 
campaigns studying this type of materials $[63,64]$, inspection campaigns on real structures $[65,66]$ or studies on historical buildings [67].

Therefore, mortar MD combines different features that might be interesting for researchers: 1) it provides a convenient strength value and, when used to build brickwork specimens, the strength values compare well with those of historical masonry elements; 2) it is based on an already premixed material, which is produced industrially and offers a controlled variability; 3) the replacement material, limestone filler, is easily available as an industrial by-product at a low cost; 4) it attains the required strength at or before 28 days, in contrast with aerial lime mortars that require much more time to harden; 5) the constant value of strength over time makes it especially suitable for the experimental research in the laboratory.

\section{Conclusions}

This paper has presented an experimental investigation on the influence of limestone filler additions on the compressive and flexural strengths of hydraulic lime mortar. The filler was added to a commercial premix in varying amounts of $12.5 \%, 25 \%, 37.5 \%$ and $50 \%$ of powder volume. Mechanical tests were carried out at 14, 28 and 56 days. The following conclusions can be drawn from these experiments:

- Limestone filler, which is an easily available industrial by-product, was successfully incorporated into mortar mixes. Mortars workability was maintained even for high amounts of material replacement.

- The influence of limestone filler depended notably on the added amount. Yet, the trend of this influence varied with the curing time and the mechanical property evaluated. The effects of filler incorporation described by previous authors for cement and aerial lime mortars could explain the observed results. 
- With the amounts of filler studied herein, a positive impact on the mechanical strengths was not consistently registered until 56 days. By that age, the nucleation effect that favours the slow reactions of hydration and carbonation was sufficiently important as to show its influence. At earlier ages, the dilution effect prevailed.

- An optimum amount of filler between $12.5 \%$ and $25 \%$ could be found to maximize the compressive and flexural strengths of NHL 3.5 based mortars. At 56 days, the mortar incorporating $25 \%$ of filler was $35 \%$ stronger than the reference mortar without filler.

- The replacement by filler of 50\% powder volume provided a mortar of almost constant mechanical strengths over time for potential applications in the research field.

- The incorporation of limestone filler, which is an inert material, doesn't affect the nature of the resulting products in the hardened mortar if compared with other hydraulic lime based mortars. Therefore, these modified mortars would be compatible with traditional old materials.

\section{Acknowledgements}

The authors gratefully acknowledge the financial support from the Ministry of Economy and Competitiveness and from the Ministry of Science, Innovation and Universities of the Spanish Government (MCIU), the State Agency of Research (AEI), as well as that of the ERDF (European Regional Development Fund) through projects MULTIMAS (Multiscale techniques for the experimental and numerical analysis of the reliability of masonry structures, ref. num. BIA201563882-P) and SEVERUS (Multilevel evaluation of seismic vulnerability and risk mitigation of masonry buildings in resilient historical urban centres, ref. num. RTI2018-099589-B-I00). Support from Secretaria d'Universitats i Investigació de la Generalitat de Catalunya through a predoctoral grant awarded to the first author is also gratefully acknowledged. 
The authors wish to thank Paolo Casadei, José Luis Sánchez and Patricio Contreras from KERAKOLL for providing part of the materials used in the experimental campaign. The support of the company PROMSA is also acknowledged, as well as the helpful contributions of Pietro Salvatoni, Matteo Ugolini and Larisa Garcia-Ramonda during the laboratory tests.

\section{References}

[1] J. Lanas, J.L. Pérez Bernal, M.A. Bello, J.I. Álvarez Galindo, Mechanical properties of natural hydraulic limebased mortars, Cem. Concr. Res. 34 (2004) 2191-2201. doi:10.1016/j.cemconres.2004.02.005.

[2] R.G. Blezard, The History of Calcareous Cements, in: P. Hewlett (Ed.), Lea's Chem. Cem. Concr., Fourth Edi, Elsevier Ltd., 2003: pp. 1-23. doi:10.1016/B978-0-7506-6256-7.50013-8.

[3] D. Krivánková, C.L. Nunes, Z. Slízková, D. Frankeová, K. Niedoba, High-Performance Repair Mortars for Application in Severe Weathering Environments : Frost Resistance Assessment, in: J.J. Hughes, J. Válek, C.J.W.P. Groot (Eds.), Hist. Mortars, Springer International, 2019: pp. 155-168.

[4] C.J.W.P. Groot, J.T.M. Gunneweg, Choosing Mortar Compositions for Repointing of Historic Masonry Under Severe Environmental Conditions, in: J.J. Hughes, J. Válek, C.J.W.P. Groot (Eds.), Hist. Mortars, Springer International, 2019: pp. 143-154.

[5] R. Veiga, Air lime mortars: What else do we need to know to apply them in conservation and rehabilitation interventions ? A review, Constr. Build. Mater. 157 (2017) 132-140. doi:10.1016/j.conbuildmat.2017.09.080.

[6] D. Gulotta, S. Goidanich, C. Tedeschi, T.G. Nijland, L. Toniolo, Commercial NHL-containing mortars for the preservation of historical architecture . Part 1 : Compositional and mechanical characterisation, Constr. Build. Mater. 38 (2013) 31-42. doi:10.1016/j.conbuildmat.2012.08.029.

[7] M.R. Veiga, A. Fragata, A.L. Velosa, A.C. Magalhaes, G. Margalha, Lime-Based Mortars : Viability for Use as Substitution Renders in Historical Buildings, Int. J. Archit. Herit. 4 (2010) 177-195. doi:10.1080/15583050902914678.

[8] A. Kalagri, I. Karatasios, V. Kilikoglou, The effect of aggregate size and type of binder on microstructure and mechanical properties of NHL mortars, Constr. Build. Mater. $53 \quad$ (2014) 467-474. doi:10.1016/j.conbuildmat.2013.11.111.

[9] S. Pavia, O. Brennan, Portland Cement-Lime Mortars for Conservation, in: J.J. Hughes, J. Válek, C.J.W.P. Groot (Eds.), Hist. Mortars, Springer International, 2019: pp. 129-142. 
[10] P. Maravelaki-Kalaitzaki, A. Bakolas, I. Karatasios, V. Kilikoglou, Hydraulic lime mortars for the restoration of historic masonry in Crete, Cem. Concr. Res. 35 (2005) 1577-1586. doi:10.1016/j.cemconres.2004.09.001.

[11] P. Faria, V. Silva, Natural Hydraulic Lime Mortars : Influence of the Aggregates, in: J.J. Hughes, J. Válek, C.J.W.P. Groot (Eds.), Hist. Mortars, Springer International, 2019: pp. 185-199.

[12] R. Hanley, S. Pavia, A study of the workability of natural hydraulic lime mortars and its influence on strength, Mater. Struct. 41(2) (2008) 373-381. doi:10.1617/s11527-007-9250-0.

[13] B.A. Silva, A.P. Ferreira Pinto, A. Gomes, Natural hydraulic lime versus cement for blended lime mortars for restoration works, Constr. Build. Mater. 94 (2015) 346-360. doi:10.1016/j.conbuildmat.2015.06.058.

[14] C. Torney, A.M. Forster, P.F.G. Banfill, E.M. Szadurski, The effects of site practice on the physical properties of proprietary stone restoration mortar, Constr. Build. Mater. $75 \quad$ (2015) 359-367. doi:10.1016/j.conbuildmat.2014.11.040.

[15] D. Gulotta, S. Goidanich, C. Tedeschi, L. Toniolo, Commercial NHL-containing mortars for the preservation of historical architecture. Part 2: Durability to salt decay, Constr. Build. Mater. 96 (2015) 198-208. doi:10.1016/j.conbuildmat.2015.08.006.

[16] P. Lopez-Arce, M. Tagnit-Hammou, B. Menendez, J.D. Mertz, M. Guiavarc'h, A. Kaci, S. Aggoun, A. Cousture, Physico-chemical stone-mortar compatibility of commercial stone-repair mortars of historic buildings from Paris, Constr. Build. Mater. 124 (2016) 424-441. doi:10.1016/j.conbuildmat.2016.07.076.

[17] L. Gil, E. Bernat-Masó, F. Cañavate, Changes in Properties of Cement and Lime Mortars When Incorporating Fibers from End-of-Life Tires, Fibers. 4 (2016) 7. doi:10.3390/fib4010007.

[18] F. Iucolano, B. Liguori, D. Caputo, F. Colangelo, R. Cioffi, Recycled plastic aggregate in mortars composition: Effect on physical and mechanical properties, Mater. Des. 52 (2013) 916-922. doi:10.1016/j.matdes.2013.06.025.

[19] J. Grilo, A.S. Silva, P. Faria, A. Gameiro, R. Veiga, A. Velosa, Mechanical and mineralogical properties of natural hydraulic lime-metakaolin mortars in different curing conditions, Constr. Build. Mater. 51 (2014) $287-294$. doi:10.1016/j.conbuildmat.2013.10.045.

[20] B. Liguori, D. Caputo, F. Iucolano, Fiber-reinforced lime-based mortars : Effect of zeolite addition, Constr. Build. Mater. 77 (2015) 455-460. doi:10.1016/j.conbuildmat.2014.12.067.

[21] S. Xu, J. Wang, Q. Jiang, S. Zhang, Study of natural hydraulic lime-based mortars prepared with masonry waste powder as aggregate and diatomite / fly ash as mineral admixtures, J. Clean. Prod. 119 (2016) $118-127$. doi:10.1016/j.jclepro.2016.01.069.

[22] M.M. Barbero-Barrera, N. Flores Medina, C. Guardia-Martín, Influence of the addition of waste graphite powder 
on the physical and microstructural performance of hydraulic lime pastes, Constr. Build. Mater. 149 (2017) 599611. doi:10.1016/j.conbuildmat.2017.05.156.

[23] S. Thirumalini, R. Ravi, M. Rajesh, Experimental investigation on physical and mechanical properties of lime mortar : Effect of organic addition, J. Cult. Herit. 31 (2018) 97-104. doi:10.1016/j.culher.2017.10.009.

[24] R. Ravi, T. Selvaraj, S.K. Sekar, Characterization of Hydraulic Lime Mortar Containing Opuntia ficus-indica as a Bio-Admixture for Restoration Applications, Int. J. Archit. Herit. $10 \quad$ (2016) 714-725. doi:10.1080/15583058.2015.1109735.

[25] Y. Benachour, C.A. Davy, F. Skoczylas, H. Houari, Effect of a high calcite filler addition upon microstructural, mechanical, shrinkage and transport properties of a mortar, Cem. Concr. Res. 38 (2008) 727-736. doi:10.1016/j.cemconres.2008.02.007.

[26] M. Galetakis, G. Alevizos, K. Leventakis, Evaluation of fine limestone quarry by-products, for the production of building elements - An experimental approach, Constr. Build. Mater. $26 \quad$ (2012) 122-130. doi:10.1016/j.conbuildmat.2011.05.011.

[27] D. Manning, Exploitation and Use of Quarry Fines. Report No. 087/MIST2/DACM/01, Mineral Solutions, 2004.

[28] E. Petavratzi, S. Wilson, Sustainable utilisation of quarry by-products, Suatainable Aggregates, 2008.

[29] A.K.H. Kwan, S.K. Ling, Filler technology for improving robustness and reducing cementitious paste volume of SCC, Constr. Build. Mater. 153 (2017) 875-885. doi:10.1016/j.conbuildmat.2017.07.160.

[30] M. Gesoglu, E. Güneyisi, M.E. Kocabag, V. Bayram, K. Mermerdas, Fresh and hardened characteristics of self compacting concretes made with combined use of marble powder, limestone filler, and fly ash, Constr. Build. Mater. 37 (2012) 160-170. doi:10.1016/j.conbuildmat.2012.07.092.

[31] E. Bacarji, R.D.T. Filho, E.A.B. Koenders, E.P. Figueiredo, J.L.M.P. Lopes, Sustainability perspective of marble and granite residues as concrete fillers, Constr. Build. Mater. $45 \quad$ (2013) 1-10. doi:10.1016/j.conbuildmat.2013.03.032.

[32] V. Bonavetti, H. Donza, G. Menéndez, O. Cabrera, E.F. Irassar, Limestone filler cement in low w / c concrete : A rational use of energy, Cem. Concr. Res. 33 (2003) 865-871. doi:10.1016/S0008-8846(02)01087-6.

[33] M. Bederina, Z. Makhloufi, T. Bouziani, Effect of limestone fillers the physic-mechanical properties of limestone concrete, Phys. Procedia. 21 (2011) 28-34. doi:10.1016/j.phpro.2011.10.005.

[34] B. Menadi, S. Kenai, J. Khatib, A. Aït-Mokhtar, Strength and durability of concrete incorporating crushed limestone sand, Constr. Build. Mater. 23 (2009) 625-633. doi:10.1016/j.conbuildmat.2008.02.005.

[35] F.M. Lea, The chemistry of cement and concrete 3rd ed., Chemical Publishing Co. Inc., 1971. 
[36] I. Soroka, N. Stern, Calcareous fillers and the compressive strength of portland cement, Cem. Concr. Res. 6 (1976) 367-376. doi:10.1016/0008-8846(76)90099-5.

[37] R.F. Feldman, V.S. Ramachandran, P.J. Sereda, Influence of $\mathrm{CaCO} 3$ on the hydration of $3 \mathrm{CaO} \cdot \mathrm{Al} 2 \mathrm{O} 3$, J. Am. Ceram. Soc. 48 (1965) 25-30.

[38] D. Wang, C. Shi, N. Farzadnia, Z. Shi, H. Jia, Z. Ou, A review on use of limestone powder in cement-based materials: Mechanism, hydration and microstructures, Constr. Build. Mater. 181 (2018) 659-672. doi:10.1016/j.conbuildmat.2018.06.075

[39] B. Benabed, H. Soualhi, B. Ase, L. Azzouz, E. Kadri, S. Kenai, Effect of limestone powder as a partial replacement of crushed quarry sand on properties of self-compacting repair mortars, J. Build. Mater. Struct. 3 (2016) 15-30.

[40] M. Aqel, D.K. Panesar, Hydration kinetics and compressive strength of steam-cured cement pastes and mortars containing limestone filler, Constr. Build. Mater. 113 (2016) 359-368. doi:10.1016/j.conbuildmat.2016.03.031.

[41] A. Fragata, R. Veiga, Air Lime Mortars : The Influence of Calcareous Aggregate and Filler Addition, Mater. Sci. Forum. 636-637 (2010) 1280-1825. doi:10.4028/www.scientific.net/MSF.636-637.1280.

[42] T. Skoulidis, D. Charalambous, K. Tsakona, Amelioration of the properties of hydrated lime for the consolidation of the surface or/and the mass of buildng materials of monuments or new buildings or statures and ornaments, in: 8th Int. Congr. Deterior. Conserv. Stone, 1996: pp. 1599-1605.

[43] A.M. Forster, N. Razali, P. Banfill, E. Szadurski, C. Torney, The influence of calcitic filler in hydraulic lime mortars for use in high temperature and high humidity climatic conditions : A preliminary investigation, in: J.J. Hughes, J. Válek, C. Groot (Eds.), Hist. Mortars, Springer International, 2019: pp. $201-211$. doi:https://doi.org/10.1007/978-3-319-91606-4.

[44] European Committee for Standardization (CEN), EN 459-1 Building lime - Part 1: Definitions, specifications and conformity criteria, (2010).

[45] European Committee for Standardization (CEN), EN 933-1 Test for geometrical properties of aggregates - Part 1: Determination of particle size distribution. Sieving method, (1997).

[46] European Committee for Standardization (CEN), EN 1015-3 Methods of test for mortar for masonry - Part 3: Determination of consistence of fresh mortar (by flow table), (1999).

[47] European Committee for Standardization (CEN), EN 1015-11 Methods of test for mortar for masonry - Part 11: Determination of flexural and compressive strength of hardened mortar, (1999).

[48] European Committee for Standardization (CEN), EN 196-1 Methods of testing cement - Part 1: Determination of strength, (2005). 
[49] A. Moropoulou, A. Bakolas, P. Moundoulas, E. Aggelakopoulou, S. Anagnostopoulou, Strength development and lime reaction in mortars for repairing historic masonries, Cem. Concr. Compos. 27 (2005) $289-294$. doi:10.1016/j.cemconcomp.2004.02.017.

[50] A. Costigan, An experimental study of the physical properties of lime mortar and their effect on lime-mortar masonry, PhD dissertation, University of Dublin, 2013.

[51] L. Pelà, P. Roca, A. Aprile, Combined In-Situ and Laboratory Minor Destructive Testing of Historical Mortars, Int. J. Archit. Herit. 12 (2018) 334-349. doi:10.1080/15583058.2017.1323247.

[52] G. Allen, Hydraulic lime mortar for stone, brick and block masonry, Routledge, 2003. doi:https://doi.org/10.4324/9781315781273.

[53] B.A. Silva, A.P. Ferreira Pinto, A. Gomes, Influence of natural hydraulic lime content on the properties of aerial lime-based mortars, Constr. Build. Mater. 72 (2014) 208-218. doi:10.1016/j.conbuildmat.2014.09.010.

[54] N. Copsey, Hiding in plain sight: hot mixed lime mortars, Loggia. 28 (2015) 118-131.

[55] M. Apostolopoulou, E.T. Delegou, E. Alexakis, M. Kalofonou, K.C. Lampropoulos, E. Aggelakopoulou, A. Bakolas, A. Moropoulou, Study of the historical mortars of the Holy Aedicule as a basis for the design, application and assessment of repair mortars : A multispectral approach applied on the Holy Aedicule, Constr. Build. Mater. 181 (2018) 618-637. doi:10.1016/j.conbuildmat.2018.06.016.

[56] F. Parisi, N. Augenti, A. Prota, Implications of the spandrel type on the lateral behavior of unreinforced masonry walls, Earthq. Eng. Struct. Dyn. 43 (2014) 1867-1887. doi:10.1002/eqe.2441.

[57] G. Rinaldin, C. Amadio, N. Gattesco, Review of experimental cyclic tests on unreinforced and strengthened masonry spandrels and numerical modelling of their cyclic behaviour, Eng. Struct. 132 (2017) 609-623. doi:10.1016/j.engstruct.2016.11.063.

[58] C.L. Knox, D. Dizhur, J.M. Ingham, Two-Story Perforated URM Wall Subjected to Cyclic In-Plane Loading, J. Struct. Eng. 144 (2018) 04018037. doi:10.1061/(asce)st.1943-541x.0002021.

[59] G. Magenes, A. Penna, A. Galasco, M. Rota, Experimental characterisation of stone masonry mechanical properties, in: 8th Int. Mason. Conf., 2010: pp. 247-256.

[60] G. Guerrini, I. Senaldi, S. Scherini, S. Morganti, G. Magenes, K. Beyer, A. Penna, Material Characterization for the Shaking-Table Test of the Scaled Prototype of a Stone Masonry Building Aggregate, in: Proc. XVII Convegno ANIDIS "L’Ingegneria Sismica Ital., 2017.

[61] J. Segura, L. Pelà, P. Roca, Monotonic and cyclic testing of clay brick and lime mortar masonry in compression, Constr. Build. Mater. 193 (2018) 453-466. doi:10.1016/j.conbuildmat.2018.10.198. 
[62] N. Makoond, L. Pelà, C. Molins, Dynamic elastic properties of brick masonry constituents, Constr. Build. Mater. 199 (2019) 756-770. doi:10.1016/j.conbuildmat.2018.12.071.

[63] N. Shetty, G. Livitsanos, N. Van Roy, D.G. Aggelis, D. Van Hemelrijck, M. Wevers, E. Verstrynge, Quantification of progressive structural integrity loss in masonry with Acoustic Emission-based damage classification, Constr. Build. Mater. 194 (2019) 192-204. doi:10.1016/j.conbuildmat.2018.10.215.

[64] L. Pelà, E. Canella, A. Aprile, P. Roca, Compression test of masonry core samples extracted from existing brickwork, Constr. Build. Mater. 119 (2016) 230-240. doi:10.1016/j.conbuildmat.2016.05.057.

[65] P. Matysek, Compressive strength of brick masonry in existing buildings — research on samples cut from the structures, in: C. Modena, F. da Porto, M.R. Valluzzi (Eds.), Brick Block Mason. - Trends, Innov. Challenges, Taylor \& Francis Group, 2016: pp. 1741-1747.

[66] J. Segura, L. Pelà, P. Roca, A. Cabané, Experimental analysis of the size effect on the compressive behaviour of cylindrical samples core-drilled from existing brick masonry, Constr. Build. Mater. 228 (2019) 116759. doi:10.1016/j.conbuildmat.2019.116759.

[67] C. Cornadó, Comportament mecànic-estructural dels edificis històrics de murs d'obra de fàbrica de maó de l’Eixample de Barcelona, $\mathrm{PhD}$ dissertation, Universitat Politècnica de Catalunya, 2015. 